\title{
EFFECT OF INVESTMENT APPRAISAL ON PERFORMANCE OF HOUSING COOPERATIVE SOCIETIES IN NORTH RIFT REGION COUNTIES
}

\author{
Mathew KiplimoKipkemboi ${ }^{1}$ and Mwengei K.B. Ombaba ${ }^{2}$ \\ ${ }^{1}$ Master of Finance and Accounting (Finance Option) \\ ${ }^{2}$ Lecturer, Jomo Kenyatta University of Agriculture and Technology
}

DOI: 10.46609/IJSSER.2020.v05i11.005 URL: https://doi.org/10.46609/IJSSER.2020.v05i11.005

\begin{abstract}
Housing is one of the largest concerns facing most countries of the world, where the increase in the numbers of the population are not corresponding with the available resources. Consequently, housing cooperative societies were introduced as a solution put forward to try to plug in the lack of housing, as part of the local communities' contributions in the housing sector, which can be considered as one of the most important actors in this sector. The housing sector in Kenya is still facing shortage of houses with regard with the number of residents in need of housing. Hence, the current study sought to mainly determine the effect of investment appraisal on performance of housing cooperatives in North region counties, Kenya. The study was guided by investment theory. The target population was 56 respondents from housing cooperatives registered by NACHU in the North Rift Region by the end of July 2018. Primary data was used and the data was collected using open self-structured questionnaires. Content validity was used to determine the validity while and Cronbach alpha coefficient was used to determine the reliability of research instrument. Data was analyzed using both descriptive and inferential statistics. For descriptive statistics frequency tables, graphs, percentages, and means were used and for inferential statistics correction and inferential statistics were used to analyze the data. The SPSS Version 24 helped in the data analysis. The study findings indicated that investment appraisal has a positive and statistically significant effect on performance of housing cooperative societies with $(\mathrm{r}=0.652 ; \mathrm{p}<0.05)$. The study concluded that Housing cooperative always establishes the cash inflows of the project and compares it with the outflows before selecting where invest. The study also recommends to the financial managers of housing cooperative association to maintain and invest in the projects which give returns on initial capital the shortest period for posterity and relevance in the market.
\end{abstract}




\section{International Journal of Social Science and Economic Research}

ISSN: $2455-8834$

Volume:05, Issue:11 "November 2020"

Keywords: Investment appraisal, Performance, Housing cooperatives society, Northrift

\section{Background of the Study}

A housing cooperative, is a legal entity, usually a cooperative or a corporation, which owns real estate, consisting of one or more residential buildings; it is one type of housing tenure (Rogers, Nelson \& Wong, 2018). Housing cooperatives are a distinctive form of home ownership that has many characteristics from other residential arrangements such as single-family home ownership, condominiums and renting (Bengtsson, Ruonavaara \& Sørvoll, 2017). The corporation is membership-based, with membership granted by way of a share purchase in the cooperative. A primary advantage of the housing cooperative is the pooling of the members' resources so that their buying power is leveraged, thus lowering the cost per member in all the services and products (Poggio \& Whitehead, 2017).

Investment appraisal is a way that a business will assess the attractiveness of possible investments or projects based on the findings of several different capital budgeting and financing techniques (Cooremans, 2012). Investment appraisal techniques are payback period, internal rate of return, net present value, accounting rate of return and profitability index (Maroyi \& van de $r$ Poll, 2012). Each technique evaluates the project from a different angle and provides a different insight. Let us understand these techniques in brief. In investment appraisal of capital expenditures, the relationship between the cost of the project and expected savings in four keyareas, absenteeism, labor turnover, spoiled and defective goods and productivity, is of special interest (Szücsné Markovics, 2016).

In Malaysia, investment appraisal is known as capital budgeting. Capital budgeting is an integral part of the corporate plan of an organization (Arslan \& Zaman, 2015). Capital budgeting can be defined as 'the process of evaluating and selecting long term investment consistent with the firm owners' goal of wealth maximization. This is one of the important decision-making process. It is a process of determining best investment appraisal which generates higher yielding in order to maximize shareholder value (Harrison \& Herbohn, 2016). More simply, capital budgeting is a stipulated avenue to invest present sum of funds more efficiently and effectively in the long run. However, Current financial theory requires that firm should maximize its market value of shares (Unger et al., 2011).

\section{Statement of the Problem}

Housing cooperatives play a significant role as social housing mechanisms for low- and moderate-income households. Housing cooperatives are useful vehicles for building community. However, the housing cooperatives in Kenya have faced challenges. Among them the failure to 
complete housing projects, poor performances and even poor structured houses. In addition, the numbers of housing projects which have stalled over the years are quite many. Studies have also shown that the number of people without proper housing is huge despite the existence of the number of housing cooperatives in the country. Kenya is a home to more than 400 housing cooperatives societies (NACHU 2016). The country has currently increased its annual production that between 40,000 and 50,000 units annually according to the Ministry of Housing. However, it is important to note that this annual production of the housing units is a global national figure. If one is to go into detail and survey the number of low-cost housing for the low-income earners, one may notice that the figures are extremely low and perhaps it is precise to say affordable housing is not affordable to all (NACHU 2016). According to WOCCU, Statistical Report 2011, there are notable challenges affecting operations of SACCOS which consequently tainted its image towards the mode of service delivery. In Kenya various types of financial organizations including micro finance organization, banks, non-bank financial institutions and cooperatives have collapsed (Maingi, 2012). As of 2009, SACCOs in Kenya were not performing very well and hence were not playing the expected vital and vibrant role in the economic growth and development of Kenya, (Kimeu, 2008). Omar (2017) finds that financial management practices are one of the important factors that influence financial capability and financial well-being of institutions and housing co-operative societies need these financial management practices for growth. Thus, the study seeks to establish the effect investment appraisal on performance of the housing cooperative societies in North Rift region counties, Kenya.

\section{Objective of the Study}

i. To determine the effect of investment appraisal on performance of housing cooperative societies in North Rift Region Counties.

\section{Research Hypothesis}

H01: Investment appraisal has no significant effect on performance of housing cooperative societies in North Rift region counties, Kenya.

\subsection{Literature Review}

\section{Theoretical Review}

The study was guided by investment theory.

\section{Investment Theory}

The theory was developed by Tobin 1969. This Theory relates to the rate of investment as a function of $\mathrm{Q}$, where $\mathrm{Q}$ is the ratio of the market value of new additional investment goods to 


\section{International Journal of Social Science and Economic Research}

ISSN: $2455-8834$

Volume:05, Issue:11 "November 2020"

their replacement cost (Tobin, 1969). If investors value assets at prices which are greater than replacement costs, then there are strong inducements for investment in reproducible real capital (Ciccoloet al 1979). Grunfeld (1960) proposed the use of the firm's market value as proxy for potential investment undertakings and further stated that investment depends on the market value of the firm in a direct correlated way, this approach to investment being influenced by the market value of the firm can be seen as a relation to Tobin's $Q$ theory. While the accelerator, neoclassical, modified neoclassical, and the cash flow models do not explicitly consider the optimal adjustment path for the firm's capital stock when it is away from that level.

This theory was relevant to the current study because it attempted to explain investment on a financial basis in terms of portfolio balance; this translates to the concept based on the q ratio; that is the ratio of the market value of capital to its replacement cost. The Q theory characterizes the complete evolution of the capital stock from the underlying optimization problem of investments differ from the preceding investment models such as the accelerator models and Jorgenson's model in that it is not output-based.

In contrast, investment is thus not viewed as a function of output as in the previous 24 models, but instead assumed that was determined by the firm's market value (Karin et al. 2008). The contrast is also elaborated by (Clark, 1979) where he states that the Q models should not be viewed as complements but rather substitutes to the standard neoclassical models. Criticism of investment theory has been pointed out that we cannot assume a constant value of the accelerator throughout the trade cycle, that is, it is not true that an increase in output or income by an amount must always give rise to a multiple increase in investment.

\section{Investment Appraisal and Performance}

According to Harris and El-Massri (2011) investment appraisal practices also known as capital budgeting means a process in which a business determines whether projects such as building a new plant or investing in a long-term venture are worth pursuing. Investment appraisal is an essential managerial tool. Capital budgeting is primarily concerned with sizable investments in long-term assets (Harris \& El-Massri, 2011). Capital budgeting decisions in manufacturing firms is the decision to invest in long-term assets like acquisition of new assets and equipment, replacements of machinery, investing in development under research and expansion of existing facilities are helpful in improving the smoothness of the production systems and deliver high quality products (Harris \& El-Massri, 2011).

Hunjra, et al., (2012) did a study on investment appraisal techniques and constraints on capital investment in Pakistan. The study employed survey research design. The target population was 63 finance executives and chief financial officers of the companies. The researcher used 


\section{International Journal of Social Science and Economic Research}

ISSN: $2455-8834$

Volume:05, Issue:11 "November 2020"

questionnaires to collect data for the study. The results showed that corporate managers are having the awareness about the worth of investment appraisal techniques and consider these techniques as important for long term profitability and survival of the company. The findings also revealed that the availability of finance, lack of profitable investment opportunities and the attitude of senior management are the major constraints on capital investment. The study however reviewed the investment appraisal techniques on capital investment compared to the current study variable.

Katabi and Dimoso (2016) examined the effect of small business characteristics on the choice of investment evaluation techniques for SMEs in Tanzania. A cross sectional design was employed by the researcher. The target population was 301 SMEs. Questionnaires and interviews were used to collect data. Study findings showed that SMEs tend to use the non-recommended investment evaluation techniques such as payback period, ARR, and gut feel. Other SMEs do not use any recommended or non-recommended investment evaluation techniques when making investment decisions. The study did not however show investment appraisal on performance of housing cooperative.

Gure and Karugu (2018) did a study on investment appraisal techniques and financial performance of small and medium enterprises in Nairobi City County, Kenya. The study employed descriptive survey research design. The target population of the study was 71,195 licensed medium enterprises with Nairobi County. The sample size was 384 Small and Medium Enterprises. The study adopted cluster random sampling technique and questionnaires to collect data. The study revealed that accounting rate of return, payback period, net present value and internal rate of return significantly affect financial performance among SME's. Besides, these results imply that payback period is most important predictor for financial performance. However, the study failed to show the effect of investment appraisal on housing cooperative.

Musau (2016) did a study on the effect of investment decision on financial performance of savings and credit cooperatives in Kenya. Empirical research design was adopted by the researcher in the study. The target population was 12 Saccos located in Kitui Town. Data was analyzed using simple multivariate analysis. Results showed that renewal decisions and research and development decisions positively contributed to performance as measured by dividends while expansion decisions had a negative contribution. Expansion decision, modernization decision and research and development decision had a positive contribution to financial performance as measured by surplus or deficits while replacement decision had a negative effect. This study however intended to fill the research gap by focusing on all the Housing societies in North Rift. 


\section{Conceptual Framework}

\begin{tabular}{|c|c|}
\hline $\begin{array}{c}\text { Investment Appraisal } \\
\text { - } \quad \text { Net Present Value } \\
\text { - Internal rate of return } \\
\text { - } \quad \text { Profitability Index }\end{array}$ & $\begin{array}{l}\text { Housing Cooperative Performance } \\
\text { - Return on Assets } \\
\text { - Return on Capital Employed } \\
\text { - Return on Investment }\end{array}$ \\
\hline
\end{tabular}

\section{Independent Variable}

\section{Dependent Variable}

\section{Figure 1.1Conceptual Framework}

\subsection{Research Methodology}

\section{Research Design}

A study was guided by a particular design, which is a plan and structure of investment conceived to obtain answers to research questions (Cooper \& Schindler, 2011). According to Mugenda (2008) a good research design clearly defines the purpose and consistency between the research question and its proposed research method. The research design that was used was census survey design. The study design enabled the researcher to obtain information about the situation at hand at one specific time. It shows the current situation of the condition under study in the desired population.

The study used a cross-sectional research design. This is because cross-sectional study was used to capture information based on data gathered for a specific point in time (Cooper et al., 2003). According to Saunders et al., (2012) exploratory research design entails merely formative examination into a subject for the purpose of gaining new insights, discovering new ideas and increasing new ideas. As the name implies, the study intends to merely explore the research problem and does not intend to offer final and conclusive solutions to existing problem but help to understand it. This study used both quantitative and qualitative approaches. The choice of a mixed research approach was used to bridge the schism between quantitative and qualitative design.

\section{Target Population}

Population means all elements and people who share one or some common quality in a special geographical scale (Oso \& Onen, 2005). Therefore, the target population for this study consisted of finance officers, managers and all credit officers working in the 12 housing cooperatives in the 
International Journal of Social Science and Economic Research

ISSN: 2455-8834

Volume:05, Issue:11 "November 2020"

North Rift Counties. The respondents of this study therefore be 12 finance officers, 12 managers and 36 credit officers total target population is 60 .

\section{Data Collection Instruments}

Research instrument is a tool used to collect, measure, and analyses data related to study subject (Brislin, 2014). The research instrument was structured questionnaire. The questionnaire contained questions on financial management practices that are budgeting techniques; financing decisions, investment appraisal techniques and working capital management also it contained questions on performance. For secondary data the data collection schedule was used to collect data.

\section{Data Collection Procedures}

The researcher obtained a letter of introduction from Jomo Kenyatta University of Agriculture and Technology. Once the research project has been approved, a research permit from National Commission for Science, Technology \& Innovation (NACOSTI) was obtained. Then the researcher then proceeded to the target institutions to seek consent to conduct the research. Once the permission is granted, the researcher sends questionnaires to each of the respondents.

\section{Pilot Study}

Pilot study was used to ascertain the validity and reliability of research instruments. A total of 5 respondents were used for the pilot study carried out in western Counties. This represents $10 \%$ of sample size for the study according to Lancaster and Williamson (2004). Kakamega County, Busia, Vihiga and Transzoia counties was chosen because have same characteristics with North Rift Counties Government.

\section{Reliability of the Research Instruments}

The reliability of a research instrument explains the extent to which the instrument yields similar results on repeated trials (Mugenda and Mugenda, 2003). Although unreliability is always observed to a certain extent, there is always a good deal of consistency in the results of a quality instrument gathered at different times. The inclination and tendency towards consistency as observed repeatedly is what constitute reliability. In this study, reliability was ensured by pre testing the questionnaire on 5 respondents at Western Counties. Cronbach's Alpha was used to tests reliability. According to Pallant (2011) a value above 0.7 is considered acceptable; however, a value above 0.8 is preferable.

Validity of the Research Instruments 
Validity refers to the degree to which an instrument accurately measures what it intends to measure. Content validity indicates the extent to which items adequately measure or represent the content of the property or trait that the researcher wishes to measure (Kimberlin \& Winterstein, 2008). The validation of the research instruments was done through approval by the supervisor who verified the face validity. Face validity is the extent to which a test measures subjectively purports to measure. The study measured content validity. To establish content validity of the measuring instrument, the researcher identified the overall content that was represented for the instrument. For proper validity checkup experts was involved in preparing the research questions in the instruments through pointing out ambiguity.

\section{Data Processing and Analysis}

Before processing the responses, the completed questionnaires were sorted, checked and edited for completeness and consistency. Data that was collected was analyzed by use of descriptive statistics to generate percentages, means, standard deviations and frequencies. This was done by tallying up responses, computing percentages of variations in response as well as describing and interpreting the data in line with the study objective and the assumptions. Tables and other graphical presentations as appropriate were used to present the data collected for ease of understanding and analysis. Also, data was analyzed using inferential statistics that is correction and multiple regression analysis. Data was analyzed by the aid of Statistical Package for Social Scientists (SPSS) at a 0.05 significance level. A regression was done and the results obtained were interpreted using tables and figures for ease of understanding.

The following regression model was used:

$\mathbf{Y}=\boldsymbol{\beta}_{0}+\boldsymbol{\beta}_{1} \mathbf{x}_{1}+\varepsilon$ .Equation 1

Where:

Y represents performance of housing cooperatives

$\boldsymbol{\beta}_{0} \quad$ represent the intercept when $\mathrm{x}$ is zero

$\mathbf{X}_{\mathbf{1}}$ represent investment appraisal techniques

$\varepsilon \quad$ represents error term

Assumptions of Regression Model 


\section{International Journal of Social Science and Economic Research}

ISSN: $2455-8834$

Volume:05, Issue:11 "November 2020"

Multiple regression is founded on several assumptions namely; linearity, homoscedasticity, normality, multicollinearity and independence of residuals. Linearity assumption implies that there is a linear relationship between the dependent variable and the set of independent variables. Linearity assumption was evaluated using ANOVA Test of linearity and residual plots. ANOVA test of linearity test $\mathrm{F}$ significance value for the nonlinear component is below the critical value is $<.05$ and then there is a significant non-linearity. Residuals for each observation in the data set were plotted on the vertical axis against the fitted value on the horizontal axis. It is expected that the residual plots show a random distribution of positive and negative values across the entire range of the variable plotted on the horizontal axis. If the residual points were scattered without an obvious pattern, there is no reason to doubt the linearity assumption (Garson, 2012).

Homoscedasticity assumption implies that the variation in the residuals is the same for both large and small values of the predicted value of the dependent variable. This was tested by plotting the residuals against the fitted values of the dependent variable. The normality assumption implies that residuals are normally distributed and have a mean of zero. To find out whether residuals follow a normal distribution, normal probability plots was used. A normal probability plot shows expected cumulative probability and observed cumulative probability on the vertical and horizontal axes respectively. If the plotted points of residuals in the normal probability plot was fairly close to a straight line drawn from the lower left to the upper right of the graph, there is no reason to doubt that the residuals are normally distributed (Lind, Marchal \& Wathen, 2012).

The assumption of multicollinearity implies that there is no correlation between independent variables. This was tested using tolerance and variance inflation factor (VIF). A tolerance of below 0.10 or a VIF greater than 10 is regarded as indicative of serious multicollinearity problems. Tolerance below 0.2 indicates a potential problem. When tolerance is close to 1 there is little multicollinearity for all independent variables. If tolerance is close to 0 , it indicates that multicollinearity may be a threat (Field, 2009; Williams, 2015). A VIF for all independent variables close to 1 and far from the threshold of 10 are considered that was having no correlation between variables hence none is removed from the analysis (Lind, Marchal \& Wathen, 2012).

The assumption of independence of residuals implies that successive observations of the dependent variable are not correlated. This means that successive residuals have no pattern and are not highly correlated and that there are no long runs of positive or negative residuals. Autocorrelation occurs when residuals are correlated. Durbin-Watson statistic was used to test for autocorrelation. The value of the Durbin-Watson statistic ranges from 0 to 4 . The value of Durbin- Watson statistic is 2.00 when there is no autocorrelation among the residuals gets close 
to 0 when there is positive autocorrelation and is beyond 2 when there is negative autocorrelation (Lind, Marchal \& Wathen, 2012).

\subsection{Research Findings and Discussion}

\section{Response Rate}

The response rate of this research study was 91.7\%. From a total of 60 administered questionnaires, 55 were completely filled and returned for data analysis. The response rate of questionnaires was appropriate for the study analysis based on Van Buuren (2018) who asserted that a response rate of 70 percent and above is satisfactory to conduct adequate data analysis. The study response rate is shown in Table 1.

Table 1.Response Rate

\begin{tabular}{lll}
\hline Category & Frequency & Percentage \\
\hline Administered & 60 & 100.0 \\
Returned & 55 & 91.7 \\
\hline
\end{tabular}

Table 2.Investment Appraisal Techniques

\begin{tabular}{|c|c|c|c|c|c|c|c|c|c|}
\hline Investment Appraisal Techniques & & $\mathbf{S A}$ & $\mathbf{A}$ & $\mathbf{N}$ & D & $\begin{array}{l}\mathbf{S} \\
\mathbf{D}\end{array}$ & Total & $\begin{array}{c}\text { Me } \\
\text { an }\end{array}$ & $\begin{array}{l}\text { Std. } \\
\text { Dev. }\end{array}$ \\
\hline \multirow{2}{*}{$\begin{array}{l}\text { 1. The housing cooperative maintains uses investment } \\
\text { appraisal techniques to evaluate a project. }\end{array}$} & $\mathrm{F}$ & 23 & 27 & 1 & 2 & 2 & 55 & \multirow{2}{*}{$\begin{array}{c}4.2 \\
2\end{array}$} & \multirow[t]{2}{*}{.937} \\
\hline & $\%$ & 41.8 & 49.1 & 1.8 & $\begin{array}{l}3 . \\
6\end{array}$ & $\begin{array}{l}3 . \\
6\end{array}$ & 100 & & \\
\hline \multirow{2}{*}{$\begin{array}{l}\text { 2. The housing cooperative maintains invests in the projects } \\
\text { which give returns initial capital the shortest period. }\end{array}$} & $\mathrm{F}$ & 21 & 28 & 1 & 4 & 1 & 55 & \multirow{2}{*}{$\begin{array}{c}4.1 \\
6\end{array}$} & \multirow[t]{2}{*}{.918} \\
\hline & $\%$ & 38.2 & 50.9 & 1.8 & $\begin{array}{l}7 . \\
3\end{array}$ & $\begin{array}{l}1 . \\
8\end{array}$ & 100 & & \\
\hline \multirow[b]{2}{*}{ 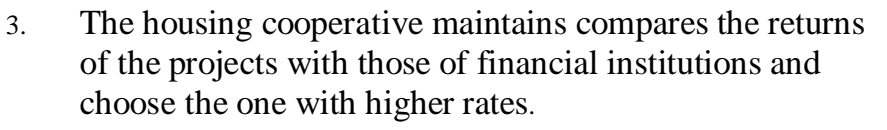 } & $\mathrm{F}$ & 21 & 30 & 0 & 3 & 1 & 55 & \multirow{2}{*}{$\begin{array}{c}4.2 \\
2\end{array}$} & \multirow[t]{2}{*}{.854} \\
\hline & $\%$ & 38.2 & 54.5 & 0.0 & $\begin{array}{l}5 . \\
5\end{array}$ & $\begin{array}{l}1 . \\
8\end{array}$ & 100 & & \\
\hline \multirow{2}{*}{$\begin{array}{l}\text { 4. The housing cooperative always establishes the cash } \\
\text { inflows of the project and compares it with the outflows } \\
\text { before selecting where invest. }\end{array}$} & $\mathrm{F}$ & 21 & 31 & 1 & 2 & 0 & 55 & \multirow{2}{*}{$\begin{array}{c}4.2 \\
9\end{array}$} & \multirow[t]{2}{*}{.685} \\
\hline & $\%$ & 38.2 & 56.4 & 1.8 & $\begin{array}{l}3 . \\
6\end{array}$ & $\begin{array}{l}0 . \\
0\end{array}$ & 100 & & \\
\hline \multirow{2}{*}{$\begin{array}{l}\text { 5. The housing cooperative selects projects with the rate of } \\
\text { return whose NPV is equal to Zero. }\end{array}$} & $\mathrm{F}$ & 16 & 32 & 7 & 0 & 0 & 55 & \multirow{2}{*}{$\begin{array}{c}4.1 \\
6\end{array}$} & \multirow[t]{2}{*}{.631} \\
\hline & $\%$ & 29.1 & 58.2 & 12.7 & $\begin{array}{l}0 . \\
0\end{array}$ & $\begin{array}{l}0 . \\
0\end{array}$ & 100 & & \\
\hline
\end{tabular}

The research sought to evaluate influence of investment appraisal techniques on performance of housing cooperatives in North Rift Counties, Kenya. The study focused on the net present value, internal rate of return, profitability index and payback period. The study was interested with the opinions of the respondents on the extent to which such constructs affect performance of 


\section{International Journal of Social Science and Economic Research}

ISSN: $2455-8834$

Volume:05, Issue:11 "November 2020"

Housing Cooperatives. The descriptive results for technological alliances were presented in Table 2.

Respondents were asked to opine on the statement that housing cooperative maintains use of investment appraisal techniques to evaluate a project and majority of the respondents 50(89.9\%) agreed with the statement. Minority of the respondents 4(5.2\%) disagreed with the statement. Further respondents accepted at (mean=4.22 and Std. Deviation=0.937) that housing cooperative maintains uses investment appraisal techniques to evaluate a project. The findings are supported by Zeng (2010) who noted that preferences and perceptions of different financing methods, are related with characteristics of both the shipping industry and specific companies. Appropriate selection of investment appraisal approach has advantage of lower cost, easier access, relatively flexible terms and conditions as well as non-disclosure of sensitive information.

The study also asked respondents to give their view on returns of the initial capital. The findings in Table 2 revealed that majority of the respondents 49(89.1\%) agreed that housing cooperative maintains invests in the project which gives returns initial capital the shortest period. Minority of the respondents $5(9.1 \%)$ disagreed with the statement. Respondents also accepted at (mean=4.16 and Std. Deviation= 0.918) that housing cooperative maintains invests in the project which gives returns initial capital the shortest period. Demba (2013) supports the findings through its findings that financial reporting and tracking through record keeping, having internal accounting experts, data management and financial information communication affect the performance to a very great extent.

Respondents also gave their opinion on internal rate of return. Findings as shown on Table 2 revealed that majority of the respondents 51(92.7\%) agreed that housing cooperative compares the returns of the projects with those of financial institutions and choose the one with higher rates. Minority of the respondents $4(7.3 \%)$ disagreed with the statement. Respondents cumulatively accepted at (mean=4.22 and Std. Deviation= 0.854) that housing cooperative compares the returns of the projects with those of financial institutions and choose the one with higher rates. The study response on profitability index as shown in Table 2 indicates that majority of the respondents 52(94.6\%) agreed that housing cooperative always establishes the cash inflows of the project and compares it with the outflows before selecting where invest. Respondents who disagreed were $2(3.6 \%)$.

Respondents accepted at (mean=4.29 and Std. Deviation= 0.685) that housing cooperative always establishes the cash inflows of the project and compares it with the outflows before selecting where invest. Further respondents were asked to give their response on payback period. The study found that majority of the respondents $48(87.3 \%)$ agreed that housing cooperative 


\section{International Journal of Social Science and Economic Research}

ISSN: $2455-8834$

Volume:05, Issue:11 "November 2020"

selects projects with the rate of return whose NPV is equal to Zero. Respondents also accepted at (mean=4.16 and Std. Deviation=0.631) that housing cooperative selects projects with the rate of return whose NPV is equal to Zero. Financial-economic experts' advice on NPV states that if a project's NPV is positive ( $>0)$, the organization can expect a profit and should consider moving forward with the investment. If a project's NPV is neutral $(=0)$, the project is not expected to result in any significant gain or loss for the company.

Table 2.Performance Housing Cooperative

\begin{tabular}{|c|c|c|c|c|c|c|c|c|c|}
\hline Performance housing cooperative & & $\mathbf{S A}$ & $\overline{\mathbf{A}}$ & $\mathbf{N}$ & $\mathbf{D}$ & SD & Total & Mean & Std. Dev. \\
\hline $\begin{array}{l}\text { 1. The housing cooperative's returns } \\
\text { are profitable relative to its assets. }\end{array}$ & $\begin{array}{l}\mathrm{F} \\
\%\end{array}$ & $\begin{array}{ll}11 \\
20.0\end{array}$ & $\begin{array}{l}39 \\
70.9\end{array}$ & $\begin{array}{ll}3 \\
5.5\end{array}$ & $\begin{array}{l}2 \\
3.6\end{array}$ & $\begin{array}{ll}0 \\
0.0\end{array}$ & $\begin{array}{l}55 \\
100\end{array}$ & 4.07 & .634 \\
\hline $\begin{array}{l}\text { 2. The use of assets by management } \\
\text { is efficient. }\end{array}$ & $\begin{array}{l}\mathrm{F} \\
\%\end{array}$ & $\begin{array}{l}11 \\
20.0\end{array}$ & $\begin{array}{l}40 \\
72.7\end{array}$ & $\begin{array}{l}2 \\
3.6\end{array}$ & $\begin{array}{l}1 \\
1.8\end{array}$ & 1 & $\begin{array}{l}55 \\
100\end{array}$ & 4.07 & .690 \\
\hline $\begin{array}{l}\text { 3. There are adequate company } \\
\text { assets. }\end{array}$ & $\begin{array}{l}\mathrm{F} \\
\%\end{array}$ & $\begin{array}{l}18 \\
32.7\end{array}$ & $\begin{array}{l}31 \\
56.4\end{array}$ & $\begin{array}{l}5 \\
9.1\end{array}$ & $\begin{array}{l}1 \\
1.8\end{array}$ & $\begin{array}{l}0 \\
0.0\end{array}$ & $\begin{array}{l}55 \\
100\end{array}$ & 4.20 & .678 \\
\hline $\begin{array}{l}\text { 4. The housing cooperative's returns } \\
\text { are profitable relative to its } \\
\text { capital employed. }\end{array}$ & $\begin{array}{l}\mathrm{F} \\
\%\end{array}$ & $\begin{array}{l}7 \\
12.7\end{array}$ & $\begin{array}{l}43 \\
78.2\end{array}$ & $\begin{array}{l}4 \\
7.3\end{array}$ & $\begin{array}{l}1 \\
1.8\end{array}$ & $\begin{array}{l}0 \\
0.0\end{array}$ & $\begin{array}{l}55 \\
100\end{array}$ & 4.02 & .527 \\
\hline $\begin{array}{l}\text { 5. The return on investment by the } \\
\text { housing cooperative is sufficient. }\end{array}$ & $\begin{array}{l}\mathrm{F} \\
\%\end{array}$ & $\begin{array}{l}11 \\
20.0\end{array}$ & $\begin{array}{l}32 \\
58.2\end{array}$ & $\begin{array}{l}4 \\
7.3\end{array}$ & $\begin{array}{l}5 \\
9.1\end{array}$ & $\begin{array}{l}3 \\
5.5\end{array}$ & $\begin{array}{l}55 \\
100\end{array}$ & 3.78 & 1.049 \\
\hline
\end{tabular}

The study further established the performance of housing cooperatives in North Rift Counties Kenya. The study focused on the return on assets, return on capital employed and return on investment. The study was interested with the opinions of the respondents on the extent to which such constructs affect performance of housing cooperatives. The descriptive results for technological alliances were presented in Table 3.

The study respondents were requested to give their opinion on the statement that housing cooperative's returns are profitable relative to its assets. The findings of the study as presented in Table 3 revealed that majority of the respondents 50(90.9\%) agreed housing cooperative's returns are profitable relative to its assets. Minority of the respondents $2(3.6 \%)$ disagreed with the statement. Respondents accepted at (mean=4.07 and Std. Deviation=0.634) that housing cooperative's returns are profitable relative to its assets. The study asked respondents to provide their opinion on the statement that the use of assets by management is efficient. The study findings as presented in Table 3 revealed that majority of the respondents 51(92.7\%) agreed and minority $2(3.6 \%)$ disagreed that the use of assets by management is efficient (mean=4.07 and Std. Deviation $=0.690)$. 
Respondents were also asked to give their opinion on the statement that there are adequate company assets. The study findings revealed that majority of the respondents 49(89.1\%) agreed and minority of the respondents $1(1.8 \%)$ disagreed with the statement that there are adequate company assets (mean=4.20 and Std. Deviation= 0.678). Respondents further gave their views on the statement that the housing cooperative's returns are profitable relative to its capital employed. Findings revealed that 50(80.9\%) of the respondents agreed that the housing cooperative's returns are profitable relative to its capital employed. Respondents who disagreed were 1(1.8\%). At (mean=4.02 and Std. Deviation= 0.527) respondents accepted that the housing cooperative's returns are profitable relative to its capital employed.

Finally, respondent was also asked to give their views on the statement that the return on investment by the housing cooperative is sufficient. Findings in Table 3 showed that majority $43(78.2 \%)$ of the respondents agreed that the return on investment by the housing cooperative is sufficient. Respondents who disagreed with the statement that return on investment by the housing cooperative is sufficient were $8(14.6 \%)$. At (mean=3.78 and Std. Deviation=1.049) respondents accepted that the return on investment by the housing cooperative is sufficient.

\section{Correlation Analysis}

The study conducted inferential analysis using Pearson's product moment correlation coefficient and regression analysis. Correlation is a statistical technique that shows how strongly pairs of variables are related. The correlation coefficient ranges from -1 to +1 . the correlation coefficient value of -1.000 indicates a perfect negative correlation and a correlation coefficient value of +0.001 to +1.000 indicates a perfect positive correlation and a correlation coefficient value of 0.000 implies that there is no relationship between the study variables (Orodho, 2013). The correlation results were as shown in Table 4.

Table 4: Test of Correlation Analysis

\begin{tabular}{|c|c|c|c|c|c|}
\hline & & $\begin{array}{l}\text { Performance of housing } \\
\text { cooperative societies }\end{array}$ & & & $\begin{array}{c}\text { Investment } \\
\text { appraisal }\end{array}$ \\
\hline $\begin{array}{l}\text { Performance of housing } \\
\text { cooperative societies }\end{array}$ & $\begin{array}{l}\text { Pearson } \\
\text { Correlation } \\
\text { Sig. (2-tailed) }\end{array}$ & 1 & & & \\
\hline \multirow[t]{2}{*}{ Investment appraisal } & $\begin{array}{l}\text { Pearson } \\
\text { Correlation }\end{array}$ & $.652^{* *}$ & .520 & $.595^{* *}$ & 1 \\
\hline & $\begin{array}{l}\text { Sig. (2-tailed) } \\
\mathrm{N}\end{array}$ & $\begin{array}{l}.000 \\
55\end{array}$ & $\begin{array}{c}.000 \\
55\end{array}$ & $\begin{array}{c}.000 \\
55\end{array}$ & 55 \\
\hline
\end{tabular}

**. Correlation is significant at the 0.01 level (2-tailed). 
The findings are shown in Table 4 which indicated that investment appraisal has a positive and statistically significant effect on performance of housing cooperative societies with $(r=0.652$; $\mathrm{p}<0.05)$. This implies that investment appraisal effects performance of housing cooperative societies in Kenya.

\section{Model Fitness}

Analysis of variance was used to determine if the multiple regression model was fit for the data. The results as shown in table 5 indicated that the effect of dependent variable was statistically significant $(\mathrm{F}=41.961 ; \mathrm{p}<0.05)$. This implied that the multiple regression model was fit for the data, therefore the overall regression model for all the variables Investment appraisal, was statistically significant and affects Performance of housing cooperative societies in Kenya.

Table 5: ANOVA Test Results

\begin{tabular}{llccccc}
\hline Model & $\begin{array}{c}\text { Sum of } \\
\text { Squares }\end{array}$ & Df & Mean Square & F & Sig. \\
\hline $\mathbf{1}$ & Regression & 22.410 & 4 & 5.603 & 41.961 & $.000 \mathrm{~b}$ \\
& Residual & 6.676 & 50 & .134 & & \\
& Total & 29.086 & 54 & & & \\
\hline
\end{tabular}

a. Dependent Variable: Performance of housing cooperative societies

b. Predictors: (Constant), investment appraisal.

\section{Regression Model Coefficients}

The T-test of statistical significance of each regression coefficient was conducted in order to determine the beta $(\beta)$ value which shows how strongly each independent variable affects the dependent variable. Table 6 shows results of the study variables; the regression coefficients. The study findings revealed that Investment appraisal had a positive and statistical significant effect on performance of housing cooperative societies $(\beta=0.138 ; \mathrm{p}<0.05)$. From Table 6.the multiple regression equation can be written as:

$\mathrm{Y}=0.652+0.138 \mathrm{X}_{1}+\varepsilon \ldots \ldots \ldots \ldots \ldots$ Equation 2

The findings can be interpreted as; at constant, Investment appraisal practices performance of housing cooperative societies is at 1.677 units. The coefficient of 0.126 indicates that an improvement in investment appraisal by one unit increases performance of housing cooperative societies by 0.126 units. 
International Journal of Social Science and Economic Research

ISSN: 2455-8834

Volume:05, Issue:11 "November 2020"

Table 6: Regression Analysis

\begin{tabular}{|c|c|c|c|c|c|}
\hline & & $\begin{array}{l}\text { lardized } \\
\text { icients }\end{array}$ & $\begin{array}{c}\text { Standardized } \\
\text { Coefficients }\end{array}$ & $\bar{t}$ & Sig. \\
\hline & B & Std. Error & Beta & & \\
\hline (Constant) & .652 & .286 & & 2.277 & .027 \\
\hline Investment appraisal & .138 & .066 & .183 & 2.083 & .042 \\
\hline
\end{tabular}

\section{Hypothesis Testing}

The third hypotheses $\left(\mathrm{H}_{01}\right)$ of the study stated that investment appraisal has no significant influence on performance of housing cooperative societies in the North Rift region counties, Kenya. The study results indicated that investment appraisal has significant influence on performance of housing cooperative societies $\left(\beta_{3}=0.138 ; \mathrm{P}=0.042<0.05\right)$. The $\beta$ factor of 0.138 implies that investment appraisal affects performance of housing cooperative societies by $13.8 \%$. The p-value of 0.042 is less than the predictable value of 0.05 which indicates that investment appraisal has a positive and statistically significant effect on performance of housing cooperative societies in the North Rift region counties, Kenya.

The findings agree with Hunjra, et al., (2012) who did a study on investment appraisal techniques and constraints on capital investment in Pakistan. And the its results showed that corporate managers are having the awareness about the worth of investment appraisal techniques and consider these techniques as important for long term profitability and survival of the company. The findings also revealed that the availability of finance, lack of profitable investment opportunities and the attitude of senior management are the major constraints on capital investment.

\subsection{Summary, Conclusion and Recommendation}

\section{Summary of the Findings}

\section{Investment Appraisal on Performance of Housing Cooperative Societies}

The study findings on investment appraisal indicated that majority of the respondents agreed that the housing cooperative always establishes the cash inflows of the project and compares it with the outflows before selecting where invest. Wise investment brings success through profit generation to the organization. Housing cooperative association considers comparison of capital outflows on the projects one of the best investment appraisal technique before selecting suitable 
International Journal of Social Science and Economic Research

ISSN: 2455-8834

Volume:05, Issue:11 "November 2020"

project for investment. Since it allows investors to diversify their risks and increase returns, and also allow residents to finance rapid rates of investment and economic growth, as well as to increase consumption. Further, investment appraisal has a positive and statistically significant effect on performance of housing cooperative societies in the North Rift region counties, Kenya

\section{Conclusions of the Study}

The study concluded that Wise investment brings success through profit generation to the organization. Housing cooperative association considers comparison of capital outflows on the projects one of the best investment appraisal technique before selecting suitable project for investment.

\section{Recommendations of the Study}

The study also recommends to the financial managers of housing cooperative association to maintain and invest in the projects which give returns on initial capital the shortest period for posterity and relevance in the market.

\section{References}

Arslan, M., \& Zaman, R. (2015). Impact of Brand Image and Service Quality on Consumer Purchase Intentions.A Study of Retail Stores in Pakistan.Global Journal of Business Research, 1(1), 9-24

Baker, H. K., Kumar, S., Colombage, S., \& Singh, H. P. (2017). Working Capital Management Practices in India: Survey Evidence. Managerial Finance. 55(4), 12-14.

Bengtsson, B., Ruonavaara, H., \& Sørvoll, J. (2017). Home Ownership, Housing Policy and Path Dependence in Finland, Norway And Sweden. In Housing Wealth and Welfare.6(4), 94-116.

Brislin, S. J., Drislane, L. E., Smith, S. T., Edens, J. F., \& Patrick, C. J. (2015). Development and Validation of Triarchic Psychopathy Scales from The Multidimensional Personality Questionnaire. Psychological Assessment, 27(3), 838.

Cooper, D. R., \& Schindler, P. S. (2011). Qualitative Research. Business Research Methods, 4(1), 160-182.

Cooremans, C. (2012). Investment in Energy Efficiency: Do the Characteristics of Investments Matter? Energy Efficiency, 5(4), 497-518. 


\section{International Journal of Social Science and Economic Research}

ISSN: $2455-8834$

Volume:05, Issue:11 "November 2020"

Garson, G. D. (2012). Testing Statistical Assumptions. Asheboro, NC: Statistical Associates Publishing.

Gure, A. K., \& Karugu, J. (2018).Investment Appraisal Techniques and Financial Performance of Small and Medium Enterprises in Nairobi City County, Kenya. International Academic Journal of Economics and Finance, 3(1), 24-43.

Harris, E. P., \& El-Massri, M. (2011). Capital Investment Appraisal. International Academic Journal of Economics and Finance, 5(1), 343-377.

Harrison, S., \& Herbohn, J. (2016). Financial Evaluation of Forestry Investments: Common Pitfalls and Guidelines for Better Analyses. Small-Scale Forestry, 15(4), 463-479.

Hunjra, A. I., Shaheen, I. B., Niazi, G. S. K., \& Rehman, I. (2012).Investment Appraisal Techniques and Constraints on Capital Investment. Actual Problems of Economics, 2(4), 12-47.

Hunjra, A. I., Shaheen, I. B., Niazi, G. S. K., \& Rehman, I. (2012).Investment Appraisal Techniques and Constraints on Capital Investment. Actual Problems of Economics, 2(4), 12-47.

Katabi, R. J., \& Dimoso, R. L. (2016). The Effect of Small Business Characteristics on The Choice of Investment Evaluation Techniques for Smes In Tanzania. International Academic Journal of Economics and Finance, 44(1), 99-113.

Kimberlin, C. L., \& Winterstein, A. G. (2008).Validity and Reliability of Measurement Instruments Used in Research. American Journal of Health-System Pharmacy, 65(23), 2276-2284.

Lancaster, G. A., Dodd, S., \& Williamson, P. R. (2004). Design and Analysis of Pilot Studies: Recommendations for Good Practice. Journal of Evaluation in Clinical Practice, 10(2), 307-312.

Lind, D. A., Marchal, W. G., \& Wathen, S. A. (2012). Statistical Techniques in Business \& Economics. New York, NY: Mcgraw-Hill/Irwin.

Maroyi, V., \& Van Der Poll, H. M. (2012).A Survey of Capital Budgeting Techniques Used by Listed Mining Companies in South Africa. African Journal of Business Management, 6(32), 9279-9292. 
Musau, M. A. (2016). Effect Of Investment Decision On Financial Performance Of Savings And Credit Cooperatives In Kitui Central Sub-County, Kenya. International Academic Journal Of Economics And Finance, 4(2), 19-23.

Oso, W. Y., \& Onen, D. O. (2005).A General Guide to Writing Research Project and Report. Kisumu: Lake Publishers.

Poggio, T., \& Whitehead, C. (2017). Social Housing in Europe: Legacies, New Trends and The Crisis. Critical Housing Analysis, 4(1), 1-10.

Rogers, D., Nelson, J., \& Wong, A. (2018). Geographies Of Hyper-Commodified Housing: Foreign Capital, Market Activity, And Housing Stress. Geographical Research, 56(4), 434-446.

Saunders, M. N., \& Lewis, P. (2012). Doing Research In Business \& Management: An Essential Guide To Planning Your Project. Pearson.

Szücsné Markovics, K. (2016). Capital Budgeting Methods Used in Some European Countries and In the United States. Universal Journal of Management, 4(6), 348-360.

Unger, J. M., Rauch, A., Frese, M., \& Rosenbusch, N. (2011). Human Capital and Entrepreneurial Success: A Meta-Analytical Review. Journal of Business Venturing, 26(3), 341-358.

Xie, C., Tinker, R., Tinker, B., Pallant, A., Hamelin, D., \& Berenfeld, B. (2011).Computational Experiments for Science Education. Science, 332(6037), 1516-1517. 